Ann. Biol. anim. Bioch. Biophys., 1976, 16 (3), 293-295.

\title{
THE PRELEPTOTENE GHROMOSOME CONDENSATION AND DECONDENSATION IN THE OVARY OF THE SHEEP EMBRYO
}

\author{
P. MAULÉON, Monique DEVICTOR-VUILLET* and J. M. LUCIANI* \\ with the technical assistance of Jacqueline BEzARD and Françoise BERTHELot
}

\author{
Station de Physiologie de la Reproduction, \\ Centre de Recherches de Tours, I.N.R.A., \\ Nouzilly, 37380 Monnaie \\ * Laboratoire d'Histologie et d'Embryologie IT, \\ Faculté de Médecine, \\ 27, boulevard Jean-Moulin, \\ 13385 Marseille Cedex 4
}

Meiosis of the germ cells of the embryonic sheep ovaries does not normally occur in organ culture when the ovary is removed before a critical period (5oth day). This has also been observed by ChalLoNer (1975) in the hamster. A cytological and histological study of the sheep gonads cultured for 6 to $\mathrm{I} 2$ day periods show that mitosis, preleptotene and few abnormal leptotene figures are then developing (MAULEON, I973, I975). The germ cells during their in vitro period keep the potential of carrying out the chain of reactions which induces meiosis as suggested by the delayed resumption of meiosis after grafting the " cultured " ovary (MAULEON, I975).

In spite of a large number of culture modifications summarised in the table I our previous conclusions remain unchallenged : whatever the conditions, the 47-49th day embryonic sheep ovaries show in culture a good structural preservation, no pycnosis, numerous germ cells with mitosis and preleptotene stages but no meiotic figures. At this age and in this species, use of the dissection method proposed by Byskov (1974) does not influence the results. Furthermore, in the rat, with the initial and classical culture conditions described by MAULEON (1973), the meiotic processes even appear if the ovary is removed very early at 13 days of gestation.

Due to these species differences, a good knowledge of the disturbances induced in culture asks for a perfect definition of the preleptotene stage in the sheep. 
TABLE I

Changes in 47-49 day embryonic sheep ovaries after 10 days in culture

Culture medium modifications

- Gonadotrophin supplements

- Total hypophyseal extracts of 54 or 100 days sheep embryo.

- Total hypophyseal extracts of adult sheep.

- LH, FSH, prolactine at different concentrations and combinations.

- Purified or crude PMSG.

- Simultaneous culture with sheep embryonic hypophyses of $52,56,90$ days of age.

- Treatments affecting steroid level

- Charcoal treated or untreated bovine calf serum.

- Male gonad added.

Culture method

- Ovary placed on grid with or without Millipore support.

- Ovary immersed in medium.

- Different $\mathrm{O}_{2}$ tension.

Organs put in culture

- Ovaries of different sizes.

- Ovarian cortex alone.

- Combined culture of ovaries of different ages.

- Mesonephric tissue with ovary or ovary dissected at the hilus junction.

\section{RESULTS AND DISCUSSION}

In the female sheep embryo, a development of chromosome condensation followed by decondensation is observed. Figures are essentially the same as those noted by WALTERS (I970, I972) in Lilium, in the human by STAHL, and LUCIANI (I97I) and in the rabbit. In this last species, a chromosome condensation with polarisation exists (DEVICTOR-VuILLET et al., 1973). An developmental series of figures characterizing the sheep embryo is proposed in plate $\mathbf{I}$.

Here, the polarised stage (IV) does not preceed but succeeds the maximal condensation (III). As the presence of a chromosome condensation stage (II) is noted in the male foetal gonad from 45 days and especially around 62 days of age such a sequence is the only possibility.

The chronology of the labelling responses in relation to the cytological stages shows :

I. A one hour $\mathrm{H}^{8}$-thymidine incorporation is found not only during precondensation (I) but also for polarisation and decondensation stages (IV and V).

2. The first radioactivity in chromosome condensation (II and III) appears around 6 to ro hours after injection. The labelling behaviour of these chromosomes is similar to prophase chromosomes at mitosis but with a long $\mathrm{G}_{2}$ phase. 
Several hypotheses can be set forth for a definition of the developmental sequence and the significance of these chromosome condensation and decondensation stages (fig. I).

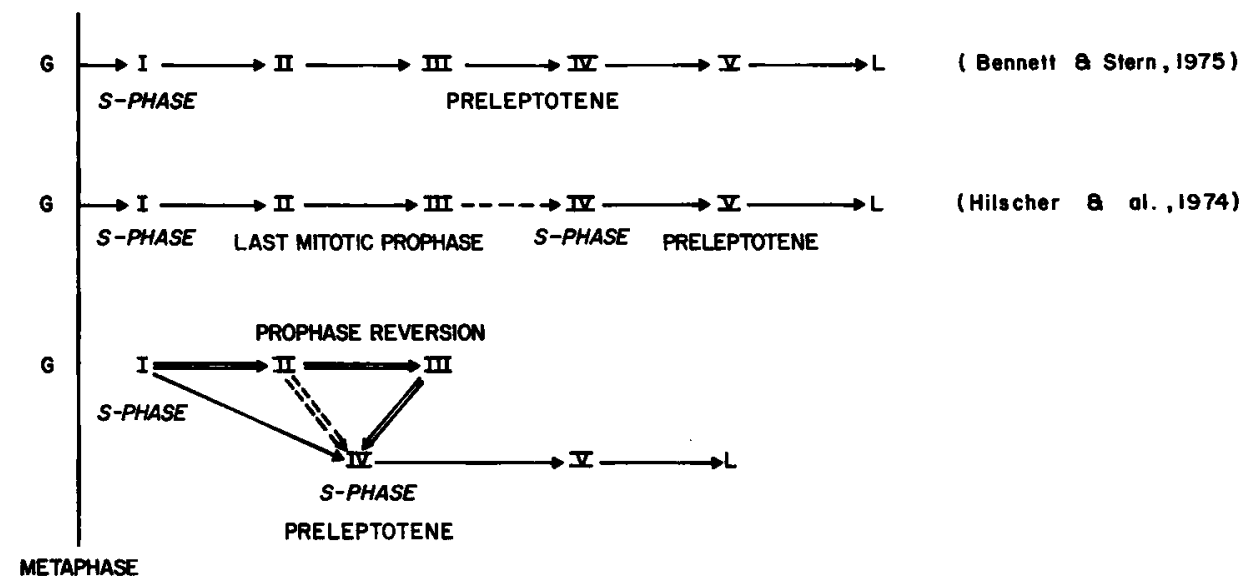

FIG. I

I. At first, it may be suggested that the period of condensation and decondensation occurs between premeiotic interphase and leptotene. These stages would represent a true mitotic reversion in which metaphase and anaphase would be omitted (BENNET and STERN, I975). However, as labelling of stages I and IV contrasts with the unlabelled stages II and III after a I or 2 hours post-injection time, such an sequence cannot be the only one in the sheep embryo.

2. Secondly, the chromosome condensation can be considered as the prophase of the last oogonial mitotic cycle, as concluded by HIISCHER et al. (I974) after histological and autoradiographic studies of rat oogenesis. The labelling pattern does not contradict this idea. If this view is accepted, metaphase and anaphase would be as frequent as the condensation stages in an adjacent area of the histological sections. They are however rare, as is the case in the cytological preparations. Besides, numerous intermediate cytological aspects are noticed between the stages III and IV suggesting a continuous development.

3. Finally, the combined evidence of cytological and autoradiographic results points at two possible developmental patterns for oogonia entering into meiosis. A short and rapid route going directly from stage I to stage IV like a classical preleptotene. A longer and slower route through the condensation stages II and III after a $\mathrm{G}_{2}$ phase following the S-phase (I) with, sometimes, a by-pass between II and IV. This variety of possibilities can accomodate the different modifications of the chromosome condensation observed in various species. For example, the maximal condensation stage (III) exists in only half the Lilium species (WALTERS, I972). In the rabbit, a similar by-pass has already been observed (DEVICTOR-VUILLET et al., I973). 


\section{RÉSUMÉ}

\section{CONDENSATION ET DÉCONDENSATION DES CHROMOSOMES PRÉLEPTOTÈ̀NES DANS L'OVAIRE EMBRYONNAIRE DE BREBIS}

La succession des différentes phases de condensation et la décondensation des chromosomes au stade préleptotène des cellules germinales d'embryon femelle de brebis est révélée par l'étude de la progression du front de marquage dans chacune de ces phases après l'injection de thymidine tritiée. La phase de condensation des chromosomes avec polarisation étant marquée une heure après l'injection du corps radioactif et celle de condensation maxima ne l'étant qu'au bout de 8 heures, ce dernier stade pourrait être une voie accessoire dans la séquence d'évolution des cellules au cours du préleptotène.

\section{REFERENCES}

BennetT M. D., Stern H., I975. The time and duration of preleptotene chromosome condensation stage in Lilium hybrid CV'Black Beauty. Proc. R. Soc. Lond. B, 188, 477-493.

Byskov A., 1974. Does the rete ovarii act as a trigger for the onset of meiosis? Nature, 252, 396-397.

Challoner S., I975. Studies of oogenesis and follicular development in the golden hamster. II. Initiation and control of meiosis in vitro. J. Anat., 119, I49-156.

Devictor-Vuillet M., Luclani J. M., Stahi, A., I973. Étude des stades de début de la méiose chez l'ovocyte de lapin. Comparaison avec l'ovocyte humain. Ann. Biol. anim. Bioch. Biophys., 13, H. S., 74-78.

Hilscher B., Hilscher W., Bulthoff-Ohnolz B., Kramer U., Birke A., Pelzer H., and GAUSS G., 1974. Kinetics of gametogenesis. I. Comparative histological and autoradiographic studies of oocytes and transitional prospermatogonia during oogenesis and prespermatogenesis. Cell. Tiss. Res., 154, 443-470.

Maulton P., r973. Modification de l'apparition et de l'évolution de la prophase méiotique dans l'ovaire d'embryon de brebis. Ann. Biol. anim. Bioch. Biophys., 13, H. S., 89-102.

MaulÉon P., I975. Importance des différentes périodes ovogénétiques dans la gonade femelle d'embryon de brebis ; contrôle du changement de comportement mitotique en méiotique. Ann. Biol. anim. Bioch. Biophys., 15, 725-737.

Srahl A., Luciani J. M., I97I. Individualisation d'un stade préleptotène de condensation chromosomique au début de la méiose chez l'ovocyte fơtal humain. C. R. Acad. Sci., Paris, Ser. D., 278, 204I-2044.

WALTERS M. S., I97o. Evidence on the time of chromosome pairing from the preleptotene spiral stage in Lilium longiflorum "croft ". Chromosoma (Berl.), 29, 375-418.

Walters M. S., 1972. Preleptotene chromosome contraction in Lilium longiflorum "croft ". Chromosoma (Berl.), 39, 3 II-332.

\section{PI,ATE I}

\section{Cytological figures of the preleptotene stages}

I. Early maximal chromosome condensation (stage II, $\times$ I 680).

2. Maximal chromosome condensation (stage III, $\times$ I 420).

3. Polarisation and early chromosome decondensation (stage IV, $\times 2800)$.

4. Chromosome decondensation (stage V, $\times$ I 680). 


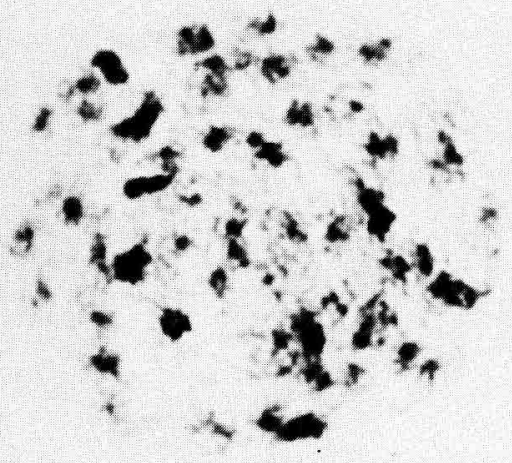

1
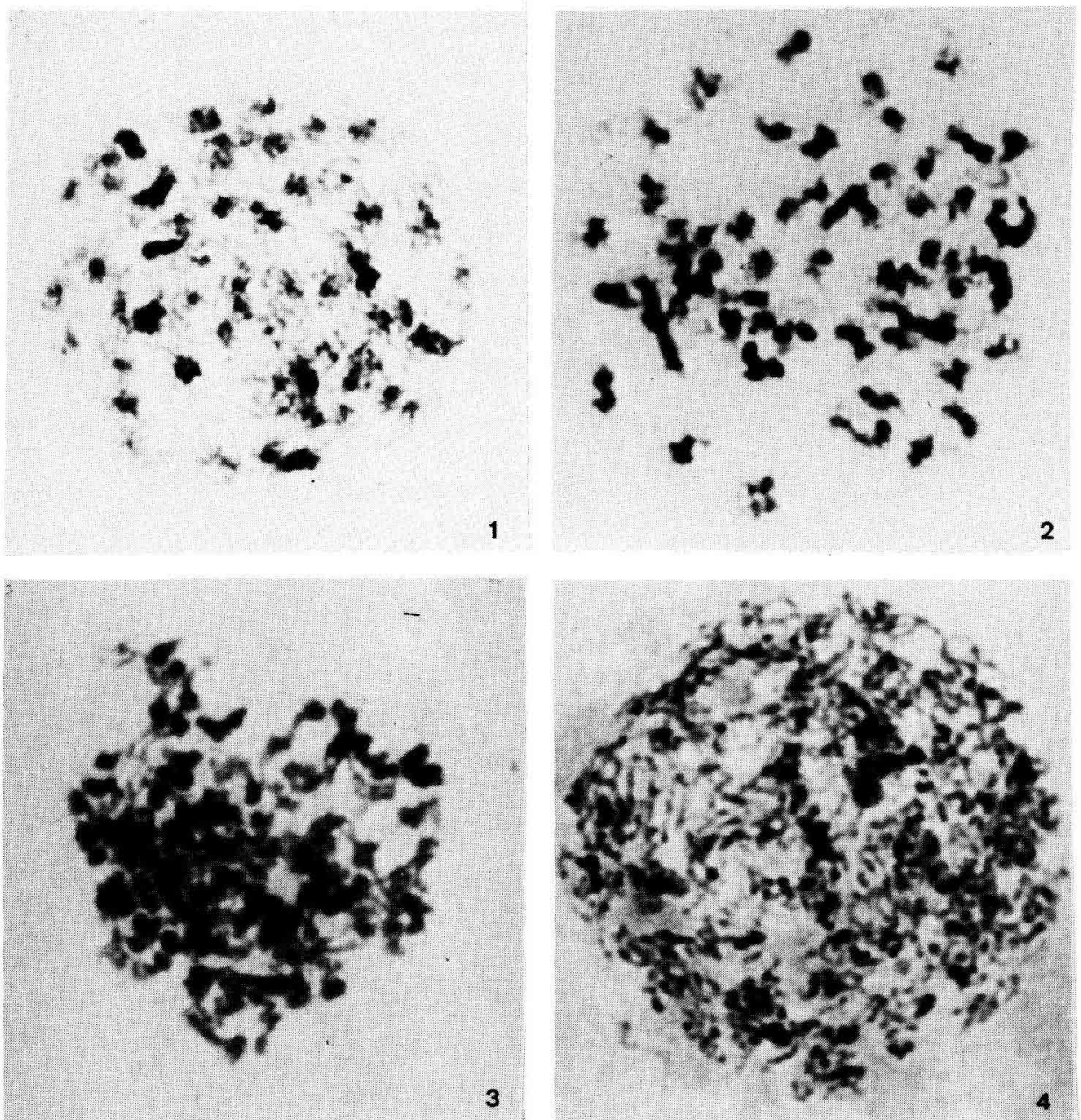